\title{
ANALISIS EFISIENSI DAN PERILAKU PASAR GULA AREN DI KECAMATAN RAMBAH SAMO KABUPATEN ROKAN HULU
}

\author{
Yogy Rasihen \\ E-mail: yogyrasihen@gmail.com \\ Jurusan Agribisnis, Fakultas Pertanian, Universitas Riau
}

\begin{abstract}
The process of distributing products from producers to end consumers requires a variety of marketing functional activities aimed at streamlining the process of delivering goods and services effectively and efficiently. The purpose of this research is to analyze marketing efficiency of palm sugar and palm sugar market behavior in Rambah Samo Sub-district of Rokan Hulu Regency. The method used is survey method. Sampling was done using Sensus method. The sample used as many as 18 samples on agroindustry of palm sugar. The analysis used is quantitative descriptive analysis. The results of this study indicate that the marketing pattern of palm sugar in Rokan Hulu District Rambah Samo through two channels but an efficient marketing channel is a marketing channel one. On the marketing channel one palm sugar producer sells it directly to the end consumer who comes directly to the production site and is sold for Rp. 20,000 / Kg. The most efficient marketing channel is channel one because it has a very small margin compared to the other channels. The behavior of sugar palm market in production center involves marketing agency that is intermediary trader. This intermediary trader who distributes palm sugar to consumers, but the role of palm sugar intermediaries in production is not much.
\end{abstract}

Keywords: palm, sugar, efficiency, marketing, consumer

\begin{abstract}
Abstrak: Proses penyaluran produk dari produsen ke konsumen akhir memerlukan berbagai kegiatan fungsional pemasaran yang ditujukan untuk memperlancar proses penyaluran barang dan jasa secara efektif dan efisien. Tujuan penelitian ini untuk menganalisis efisiensi pemasaran gula aren dan perilaku pasar gula aren di Kecamatan Rambah Samo Kabupaten Rokan Hulu. Metode yang digunakan adalah metode survei. Pengambilan sampel dilakukan dengan menggunakan metode sensus. Sampel yang digunakan sebanyak 18 sampel pada agroindustri gula aren. Analisis yang digunakan adalah analisis deskriptif kuantitatif. Hasil penelitian ini menunjukkan bahwa pola pemasaran gula aren yang ada di Kecamatan Rambah Samo Kabupaten Rokan Hulu melalui dua saluran namun saluran pemasaran yang efisien adalah saluran pemasaran satu. Pada saluran pemasaran satu pengrajin gula aren menjualnya langsung ke konsumen akhir yang datang langsung ke lokasi produksi dan dijual dengan harga Rp. $20.000 / \mathrm{Kg}$. Saluran pemasaran yang paling efisien adalah saluran satu karena memiliki margin yang sangat kecil dibandingkan dengan saluran yang lain. Perilaku pasar gula aren di sentra produksi melibatkan lembaga pemasaran yaitu pedagang perantara. Pedagang perantara inilah yang mendistribusikan gula aren sampai ke konsumen, namun peran perantara gula aren disentra produksi tidak banyak.
\end{abstract}

Kata kunci: gula, aren, efisiensi, pemasaran, konsumen

\section{PENDAHULUAN}

Keunggulan komparatif yang dimiliki dalam produksi pertanian terutama lahan yang luas dan subur, iklim yang baik dan tenaga kerja yang banyak lambat laun semakin berkurang digantikan oleh keunggulan kompetitif. (Tambunan, 2010). Menurut Arifin (2005) 
pembangunan pedesaan yang dirangsang oleh agroindustri dengan pertimbangan bahwa sumberdaya di pedesaan lebih banyak menunjang produksi pertanian karena mengandalkan lahan dan tenaga kerja. Agroindustri sebagai salah satu subsistem penting dalam sistem agribisnis yang memiliki potensi untuk mendorong pertumbuhan ekonomi yang tinggi karena pangsa pasar dan nilai tambah yang relatif besar dalam produk nasional. Sebagai penggerak pembangunan pertanian, agroindustri diharapkan dapat memainkan peranan penting kegiatan pembangunan daerah dalam sasaran pemerataan pembangunan ekonomi. Keberadaaan agroindustri di pedesaan diharapkan dapat meningkatkan permintaan terhadap komoditas pertanian.

Aren merupakan salah satu komoditi perkebunan yang menjadi pilihan secara ekonomi bagi masyarakat di Kabupaten Rokan Hulu. Sentra produksi gula aren di Kabupaten Rokan Hulu salah satunya di Kecamatan Rambah Samo. Produksi aren pada tahun 2014 di Kecamatan Rambah Samo sebesar 4,63 ton, Kecamatan Rambah 4,95 ton dan Kecamatan Bangun Purba 4,62 ton (BPS Kabupaten Rokan Hulu, 2015). Nira aren sebagai bahan baku agroindustri gula aren diperoleh dari pohonpohon aren yang ada di daerah tersebut. Agroindustri yang menghasilkan gula aren ini termasuk kedalam agroindustri skala kecil yang dibina oleh Dinas Perindustrian dan Perdagangan Kabupaten Rokan Hulu. Agroindustri ini menunjukkan perkembangan yang baik, bisa dilihat dari segi kemasan yang telah dibuat lebih menarik dan moderen. Produk gula aren yang dihasilkan di Kabupaten Rokan Hulu berupa gula aren cetak (padat) maupun produk gula aren berbentuk serbuk (bubuk) dengan nama gula semut.

Produksi gula aren di Kecamatan Rambah Samo Kabupaten Rokan Hulu adalah gula aren yang memiliki kualitas bagus, dan masih dapat terus dikembangkan, karena didaerah ini terkenal sebagai penghasil gula aren tradisional yang diolah dari nira pohon aren (Arenga pinnata) yang diusahakan secara turun temurun, dimana pohon arennya tidak dibudidayakan. Jika melihat kondisi pada saat ini peluang produk gula aren untuk terus dikembangkan sangatlah besar mengingat permintaan pasar sangatlah tinggi. Gula Aren ini dipasarkan ditingkat lokal dan tingkat provinsi, ditingkat lokal pengrajin aren membawa hasil produksinya ke pasar- pasar yang ada diwilayah Kecamatan Rambah Samo Kabupaten Rokan Hulu dan juga dipasarkan diwarung-warung yang menjual kebutuhan rumah tangga, sedangkan untuk pemasaran Provinsi, dimanfaatkan untuk kegiatankegiatan pameran dan sebagai oleh-oleh. Pelaku-pelaku kegiatan dalam pemasaran gula aren baik sebagai pedagang pengumpul (whole seller), pedagang pengecer (retailer) yang mempunyai peran masing-masing dalam menyalurkan gula aren dari produsen sampai ke konsumen. Hanya saja usaha agroindustri gula aren ini masih banyak mengalami kendala diantaranya kualitas dan kontinuitas produk yang belum terjamin dan jarang melakukan inovasi produk terutama dalam pemasaran. Selain itu kemasan produk yang kurang menarik, pemasaran yang terbatas karena kurangnya promosi. Oleh karena itu perlu dilakukan penelitian efisiensi dan perilaku pasar gula aren di Kecamatan Rambah Samo. Penelitian ini bertujuan untuk menganalisis efisiensi dan perilaku pasar gula aren di Kecamatan Rambah Samo Kabupaten Rokan Hulu.

\section{METODE PENELITIAN}

Penelitian ini dilakukan di Kecamatan Rambah Samo di Kabupaten Rokan Hulu, Riau. Pemilihan lokasi ini dilakukan secara sengaja (purposive), dengan pertimbangan bahwa Kecamatan Rambah Samo merupakan Kecamatan sentra produksi aren di Kabupaten Rokan Hulu, yang memproduksi gula aren. Penelitian dilaksanakan mulai bulan November 2016

Metode yang digunakan dalam penelitian adalah metode survei, yaitu penelitian yang dilakukan melalui pengumpulan informasi dari populasi secara langsung ditempat kejadian menggunakan kuesioner dengan tujuan untuk mengetahui pendapat dari sebagian populasi yang diteliti terhadap permasalahan. Penarikan sampel petani/pengrajin dilakukan dengan cara sensus yaitu yaitu sebanyak 18 petani aren.

Untuk menganalisis tingkat efisiensi pemasaran gula aren di kecamatan Rambah Samo dilakukan dengan menganalisis efisiensi 
pemasaran dan perilaku pasar. Perilaku pasar gula aren dianalisis secara deskriptif kuantitatif dan efisiensi pemasaran dianalisis secara kuantitatif. Efisiensi pemasaran adalah perbandingan antara total biaya pemasaran terhadap total nilai produk (harga beli pada konsumen). Untuk menghitung efisiensi pemasaran (Soekartawi, 2002) digunakan rumus sebagai berikut.

$$
\mathrm{Ep}=\frac{\mathrm{TBP}}{\operatorname{TNP}} \times 100 \%
$$

Keterangan:

$\begin{array}{ll}\text { Ep } & =\text { Efisiensi pemasaran } \\ \mathrm{TBP} & =\text { Total biaya pemasaran } \\ (\mathrm{Rp} / \mathrm{kg}) & \\ \mathrm{TNP} & =\text { Total nilai produk yaitu } \\ & \text { harga beli pada konsumen } \\ & (\mathrm{Rp} / \mathrm{kg})\end{array}$

\section{HASIL DAN PEMBAHASAN}

\section{Profil Agroindustri Gula Aren}

Gula aren diperoleh dari sari gula atau yang sering disebut sebagai nira, yaitu tangkai bunga jantan yang dapat disadap ketika tanaman aren berumur lima tahun dengan puncak produksi pada umur 15-20 tahun. Nira diolah menjadi gula dalam bentuk padat, bubuk dan cair, atau dapat pula diolah lebih lanjut menjadi cuka dan alkohol. Gula aren berbeda dengan gula biasa dibandingkan dengan gula pasir, gula dari pohon aren ini dapat digunakan untuk semua keperluan, mulai dari pemanis minuman, dan bumbu masakan. Agroindustri gula aren di Kecamatan Rambah Samo dijadikan sebagai matapencaharian pokok maupun sampingan untuk menunjang perekonomian masyarakat. Agroindustri gula aren sudah dilakukan selama berpuluh tahun dan menjadi warisan turuntemurun dari nenek moyang. Kegiatan pengolahan gula aren di Kecamatan Rambah dilakukan karena agroindustri gula aren ini akan terus berjalan dan tidak akan punah serta keinginan untuk memanfaatkan sumberdaya alam yang ada demi kesejahteraan hidup mereka.

Nira aren sebagai bahan baku ketersediaannya sudah semakin berkurang karena penyadapan yang dilakukan secara terus menerus, sehingga pohon aren tidak bisa lagi memproduksi air nira setelah berproduksi lebih kurang 8 - 10 tahun selain itu umur tanaman yang sudah lama dan tua menyebabkan pohonpohon aren banyak yang mati. Selain itu adanya alih fungsi lahan ke tanaman perkebunan lainnya. Adanya upaya yang dilakukan dinas atau pemerintah daerah untuk tetap melestarikan pohon aren dengan memberikan bantuan bibit tahun 2005 untuk dibudidayakan namun hanya $30 \%$ saja yang bertahan hidup, sehingga para pengrajin melakukan usaha gula aren dengan memanfaatkan pohon aren yang masih ada. Menurut Burhanuddin (2005) perluasan budidaya dan rekayasa teknologi pembibitan tanaman aren dapat membantu upaya pelestarian tanaman ini sebab selama ini hanya mengandalkan faktor alam. Aktivitas pembibitan tersebut berpeluang besar sebagai sumber pendapatan tambahan bagi masyarakat.

\section{Analisis Pemasaran Gula Aren}

\section{Saluran Pemasaran Satu}

Marjin pemasaran adalah selisih harga dari dua tingkat rantai pemasaran atau selisih harga yang dibayarkan di tingkat konsumen dengan harga yang diterima produsen. Dengan kata lain, marjin pemasaran merupakan perbedaan harga ditingkat konsumen dengan harga di tingkat produsen (Rahim dan Diah, 2007). Pada saluran pemasaran satu, pengrajin menjual gula arennya ke konsumen akhir yang datang langsung ke lokasi pengrajin. Saluran pemasaran satu dapat dilihat pada Tabel 1.

Pola pemasaran gula aren pada saluran pemasaran satu dilakukan dengan cara pengrajin mendistribusikan gula aren ke konsumen akhir. Biaya pemasaran yang dikeluarkan berupa biaya Kemasan Plastik Rp. $727 / \mathrm{Kg}$ dengan total penerimaan bersih yang diterima pengrajin sebesar Rp. 19.273/Kg. Harga jual gula aren pengrajin ke konsumen akhir yaitu Rp. 20.000/Kg. Hasil penelitian menunjukkan margin pemasaran pada saluran satu di Kecamatan Rambah Samo Kabupaten Rokan Hulu bernilai 0, karena pada saluran pemasaran satu ini pengrajin gula aren berperan langsung sebagai penjual/pedagang. Pengrajin sebagai penjual/pedagang dengan menjual gula aren dilokasi pembuatan atau produksi dapat menentukan harga jual dan jumlah produksi gula aren yang ingin dijual ke konsumen. 
Keuntungan pada saluran pemasaran satu ini lebih besar karena biaya pemasaran yang dikeluarkan tidak terlalu besar, sehingga pengrajin mampu mengambil resiko dengan menjualnya langsung konsumen akhir.

Faktor yang mempengaruhi kelancaran arus barang dari produsen ke konsumen adalah memilih saluran pemasaran yang tepat dan efisien. Saluran pemasaran dikatakan efisien ditinjau dari banyaknya variabel seperti yang di kemukakan oleh (Soekartawi, 2010) yang mengatakan bahwa setiap penambahan biaya pemasaran dan semakin kecil nilai produksi yang dijual, ini berarti bahwa pemasaran tidak efisien. Untuk komoditi pertanian pemasaran ditentukan oleh keadaan harga yang menguntungkan.

Berdasarkan hasil penelitian saluran pemasaran satu diperoleh nilai efisiensi sebesar 3,64\%. Efisiensi pemasaran pada saluran satu berada pada peringkat pertama dari dua saluran pemasaran gula aren yang ada di Kecamatan Rambah Samo Hal ini dikarenakan pengrajin menjual gula arennya Rp. $20.000 / \mathrm{kg}$, berbeda dengan saluran dua pedagang menjual kembali gula aren ke konsumen dengan hrga Rp $24.000 / \mathrm{kg}$. Bagian harga yang diterima oleh pengrajin pada saluran satu berjumlah $100 \%$ tanpa ada biaya pemasaran seperti transportasi dan biaya pajak pasar. Pada saluran satu pengrajin berperan langsung sebagai pedagang dengan menjual secara langsung di tempat produksi.

\section{Saluran pemasaran dua}

Pola pemasaran gula aren pada saluran pemasaran dua didistribusikan pengrajin ke pedagang pengecer yang berperan sebagai perantara dalam memasarkan gula aren di Kecamatan Rambah Samo. Pedagang pengecer yang berperan sebagai penyalur dalam penyediaan gula aren dipasar kecamatan dan kabupaten, tidak terlepas dari hubungan dengan pengrajin. Pedagang sangat bergantung kepada pengrajin dalam pemasaran gula aren, berapapun gula aren yang dihasilkan pengrajin setiap harinya, pedagang akan mengambilnya dari pengrajin.

Pola pemasaran gula aren yang didistribusikan pengrajin kepada pedagang pengecer dan dari pedagang dijual kepada konsumen akhir. Biaya pemasaran yang dikeluarkan pengrajin hanya biaya kemasan plastik Rp. 475/Kg, dengan penerimaan bersih pengrajin sebesar Rp. 19.525/Kg. Harga jual gula aren yang ditentukan pengrajin ke pedagang pengecer yaitu Rp. 20.000/Kg. Biaya pemasaran yang dikeluarkan oleh pedagang pengecer di Kecamatan Rambah Kabupaten Rokan Hulu yaitu biaya transportasi, pajak pasar dan biaya kemasan plastik.

Tabel 1. Saluran Pemasaran Satu Gula Aren di Kabupaten Rokan Hulu

\begin{tabular}{clrr}
\hline No & \multicolumn{1}{c}{ Keterangan } & Jumlah $(\mathrm{Rp} / \mathrm{Kg})$ & $\%$ \\
\hline A & Pengrajin & 20.000 & \\
& 1. Harga Jual & 727 & 4 \\
& 2. Biaya Pemasaran & 727 & 3,64 \\
& Kemasan Plastik & 19.273 & \\
& 3. Penerimaan & & \\
B & Konsumen & 20.000 & 0,49 \\
& 1. Harga Beli & 99 & \\
& 2. Transportasi Konsumen & 727 & \\
C & Total Biaya Pemasaran & 0 & 3,64 \\
D & Total Margin Pemasaran & 19.273 & 100 \\
E & Total Keuntungan & & \\
F & Efisiensi Pemasaran & & \\
G & Bagian Yang Diterima Pengrajin & &
\end{tabular}


Yogy Rasihen: Analisis Efisiensi dan Perilaku Pasar Gula Aren...

Tabel 2. Saluran Pemasaran Dua Gula Aren di Kabupaten Rokan Hulu

\begin{tabular}{clcc}
\hline No & \multicolumn{1}{c}{ Keterangan } & Jumlah $(\mathrm{Rp} / \mathrm{Kg})$ & $\%$ \\
\hline A & Pengrajin & 20 & \\
& 1. Harga Jual & 475 & 2,38 \\
& 2. Biaya Pemasaran & 475 & 2,38 \\
& Kemasan Plastik & 19.525 & \\
& Penerimaan & & \\
B & Pedagang Pengecer & 20 & \\
& 1. Harga Beli & 24.4 & 7,98 \\
& 2. Harga Jual & 1.596 & 5,11 \\
& 3. Biaya Pemasaran & 1.021 & 0,5 \\
& Transportasi & 100 & 2,38 \\
& Biaya Pajak Pasar & 475 & \\
& Kemasan Plastik & 4.4 & \\
& 4. Margin Pemasaran & 2.804 & \\
& 5. Keuntungan & & \\
& Konsumen & 24.4 & \\
C & 1. Harga Beli & 2.071 & \\
D & Total Biaya Pemasaran & 4.4 & \\
E & Total Margin Pemasaran & 2.329 & \\
F & Total Keuntungan & & \\
G & Efisiensi Pemasaran & & \\
H & Bagian Yang Diterima Pengrajin & &
\end{tabular}

Biaya transportasi yang dikeluarkan oleh pedagang pengecer adalah sebesar Rp. $1.021 / \mathrm{Kg}$, biaya pajak pasar yang dikenakan oleh pedagang pengecer yaitu Rp. $100 / \mathrm{Kg}$, Pedagang pengecer menjual gula aren di pasar yang berada di Kecamatan Rambah dan warung/toko milik sendiri dirumahnya. Biaya kemasan plastik sebesar Rp. 475/Kg sehingga total biaya pemasaran yang dikeluarkan oleh pedagang pengecer yaitu Rp. $1.596 / \mathrm{Kg}$ dan harga jual gula aren pedagang pengecer ke konsumen adalah sebesar Rp. 24.400/Kg. Sementara itu, total biaya pemasaran yang dikeluarkan untuk saluran pemasaran dua adalah Rp.2.071/Kg.

Biaya penyusutan pada pedagang gula aren di Kabupaten Rokan Hulu dikategorikan sangat kecil, karena gula aren tidak mudah rusak dan jalur pemasarannya tidak begitu panjang sehingga gula aren ini jika di simpan ditempat yang tertutup tahan hingga \pm 4-6 bulan, sehingga resiko kerugian yang dialami pengrajin maupun pedagang tidak begitu besar. Pedagang pengecer yang berada di pasar Kecamatan Rambah tidak mengeluarkan biaya pengemasan/penyimpanan karena produk gula aren tidaklah mudah rusak. Total margin pemasaran pada saluran pemasaran dua adalah Rp. 4.400/Kg yang didapat dari selisih harga yang diterima pengrajin

Menurut Mubyarto dalam Haryunik (2002), pemasaran untuk komoditas pertanian dalam suatu sistem pemasaran dianggap efisien apabila mampu menyampaikan hasilhasil dari produsen kepada konsumen dengan biaya semurah-murahnya dan mampu mengadakan pembagian yang adil dari keseluruhan harga yang dibayar konsumen akhir kepada semua pihak yang ikut serta di dalam kegiatan produksi dan pemasaran. Berdasarkan hasil penelitian, nilai efisiensi pemasaran gula aren pada saluran dua di Kecamatan Rambah Samo adalah 8,49\%. Hasil penelitian menunjukkan bahwa efisiensi pemasaran pada saluran dua lebih besar dari pada saluran pemasaran satu.

Pemasaran gula aren memerlukan lembaga pemasaran sebagai perantara. Perilaku pasar pada saluran gula aren dilihat dari lembaga pemasaran dan penentuan harga jual 
gula aren. Pada kedua saluran pemasaran terlihat pada saluran dua saja yang melibatkan perantara yaitu pedagang pengecer untuk memasarkan gula aren ke konsumen. Saluran dua adalah saluran pemasaran tidak langsung. Saluran satu adalah saluran distribusi langsung. Menurut Subroto (2011) saluran pemasaran langsung adalah suatu strategi penjualan produk kepada pelanggan tanpa menggunakan perantara. Namun pada pemasaran gula aren yang dilakukan untuk kedua saluran, penentuan harga ditentukan sendiri oleh pengrajin. Pengrajin memiliki kekuatan dalam menentukan harga jual gula aren yang diberikan kepada konsumennya. Kekuatan pengrajin dalam menentukan harga jual tentulah akan menguntungkan bagi pengrajin itu sendiri sehingga pengrajin bisa memilih kepada siapa gula aren akan dijual. Berbeda dengan pemasaran gula kelapa di Kabupaten Indragiri Hilir Riau, ketergantungan pengrajin kepada pedagang pengumpul menyebabkan ketidakmampuan pengrajin menentukan harga yang sesuai dengan pasar (Maharani et all, 2011).

\section{KESIMPULAN DAN SARAN}

Pola pemasaran gula aren di Kecamatan Rambah Samo pada saluran satu, pengrajin menjualnya langsung ke konsumen akhir yang datang langsung ke tempat produksi dengan harga jual Rp. 20.000/Kg sedangkan pada saluran pemasaran dua dimulai dari pengrajin yang menjual gula aren kepada pedagang pengecer dengan harga Rp. $20.000 / \mathrm{Kg}$ dan pedagang menjualnya kembali kepada konsumen akhir yang berada di pasar Kecamatan Rambah Samo dengan harga Rp. $24.400 / \mathrm{Kg}$. Saluran pemasaran yang paling efisien adalah saluran pemasaran satu karena memiliki margin yang sangat kecil dibandingkan dengan saluran pemasaran dua. Keuntungan yang diterima pengrajin pada saluran satu sebesar Rp. 19.273/Kg, sementara pada saluran dua sebesar Rp. 2.329/Kg. Penerimaan pengrajin pada saluran pemasaran satu sebesar Rp. 19.273/Kg, pada saluran dua memperoleh penerimaan sebesar $\mathrm{Rp}$. $19.525 / \mathrm{Kg}$.

Perilaku pasar pada pemasaran gula aren di Kecamatan Rambah Samo dilihat dari lembaga pemasaran dan penentuan harga jual.
Pada saluran pemasaran satu tidak melibatkan lembaga pemasaran namun harga jual gula aren ditentukan sendiri oleh pengrajin. Berbeda dengan saluran pemasaran dua melibatkan lembaga perantara dan harga ditentukan oleh pengrajin.

Saran penelitian ini diharapkan pengrajin mencari peluang pasar gula aren untuk meningkatkan pendapatannya.

\section{DAFTAR PUSTAKA}

Arifin, Bustanul. 2005. Pembangunan Pertanian. Penerbit Grasindo Jakarta.

Badan Pusat Statistik. 2015. Rokan Hulu Dalam Angka. Provinsi Riau.

Baharuddin. 2005. Prospek Pengembangan Usaha Koperasi dalam Produksi Gula Aren. Jakarta

Haryunik, R. 2002. Analisis Efisiensi Pemasaran Beras Organik di Desa Mangunsari Kecamatan Sawangan Kabupaten Magelang. Tesis. Program Studi Ekonomi Pertanian. Kelompok Bidang Ilmu-ilmu Pertanian. Program Pascasarjana. Universitas Gajah Mada. Yogyakarta. Tidak Dipublikasikan.

Maharani, Evy, Edwina S, Kusumawaty, Y. 2011. Pemasaran Gula Kelapa di Kabupaten Indragiri Hilir Melalui Pendekatan Struktur, Perilaku dan Penampilan Pasar. Jurnal Ilmu Ekonomi Pertanian Indonesia Volume 2 Nomor 1, Juli 2011.

Rahim, A dan Hastuti Diah, D. 2007. Ekonomika Pertanian. Penebar Swadaya. Jakarta.

Soekartawi, dkk. 2002. Prinsip Dasar Ekonomi, Teori dan Aplikasinya. Jakarta: PT Raja GrafindoPersada.

Soekartawi. 2010. Agribisnis Teori dan Aplikasi. Rajawali Press. Jakarta.

Subroto, Budiarto. 2011. Pemasaran Industri. Penerbit Andi Yogyakarta.

Tambunan, Tulus. 2010. Pembangunan Pertanian dan Ketahanan Pangan. Penerbit UI Press Jakarta. 